\title{
Chapter 15 \\ Diaspora Policies, Consular Services and Social Protection for Irish Citizens Abroad
}

\author{
Mary J. Hickman
}

\subsection{Introduction}

This chapter will show that Irish policies for citizens abroad are characterized by an intention to maximise the usefulness of the diaspora for Irish national interests and by a commitment to address the welfare, cultural and other needs of the Irish abroad and strengthen links between Ireland and its diaspora. The chapter commences with an outline of some demographic characteristics of the Irish diaspora and an account of the main structures and policies of the Irish Government's engagement with its diaspora. It continues with a more detailed examination of the social protection policies that include the Irish abroad and indicates the main principles that underpin this aspect of engagement with the diaspora. The chapter concludes by summarising some of the ways in which Irish diaspora policies are changing.

\subsection{Diaspora Characteristics and Home Country Engagement}

\subsubsection{The Irish Diaspora and Its Relations with the Homeland}

Irish migration in the nineteenth century was one of the most significant movements of population in modern European history as regards both the total number of people involved and the proportion of the population migrating. In 1841, before the

\footnotetext{
M. J. Hickman $(\bowtie)$

Maynooth University Social Sciences Institute (MUSSI), Maynooth University,

Kildare, Ireland

e-mail: mary.hickman@mu.ie
} 
Great Famine, the population of the area now known as (Republic of) Ireland was 6.5 million. By 1961, the total was down to 2.8 million, and in 2018 the population had only climbed back to 4.86 million. ${ }^{1}$ Between 1801 and 1921, approximately 8 million people left the island of Ireland. During the past century, the outflow has been in excess of 1.5 million. For example, in the period 1949-1989, 800,000 people left the Republic of Ireland. The return to net outward migration in 2009 represented the beginning of the third period of heavy Irish emigration since 1945 (see Walter el al. 2002; Glyn et al. 2013).

Consequently, at any one time a significant proportion of people who were born in Ireland are living abroad (17.5\% according to the OECD in 2014) and there are many millions of people across the globe of Irish descent. Many claim an Irish identity and down to the third generation (a grandparent born in Ireland) can claim Irish citizenship. According to the figures of the Department of Foreign Affairs and Trade, there are estimated to be 3.8 million citizens living outside Ireland, up to half live in Northern Ireland. The prime destinations for Irish migrants have been first, in the nineteenth century, the United States of America (USA), and then, in the twentieth century, the United Kingdom (UK), mainly England. In 2013, the United Nations estimated that there were 412,658 people born in the Republic living in the UK; and 143,500 in the USA. Since the 1950s, there has been a notable on-going movement to Australia, with young Irish people having easy access to short-term visas (77,513 in 2013). Other significant destinations include Canada, New Zealand and increasingly the rest of the European Union (EU), with Spain having the largest number (17,519 in 2013).

Until the last years of the twentieth century, Irish Governments were ambivalent at best about the Irish diaspora. There had been efforts to deal with emigration in the 1950s, with a Report of the Commission on Emigration. ${ }^{2}$ In 1984, the DION committee, the forerunner of the Emigrant Support Programme (ESP), was established to assist emigrants in Britain whose welfare needs were acknowledged. Prior to this, the main institution supporting Irish emigrants in the top settlement destinations was the Catholic Church. However, after the out migration of the 1980s, many more secular organisations were established in the diaspora to support and advise Irish emigrants and their children.

\subsubsection{Diaspora Infrastructure}

Ireland has a network of 63 embassies, 10 consul generals, and a number of honorary consuls making up 80 representations all together. This is acknowledged to be moderate by international standards. In countries not covered, Ireland relies on

\footnotetext{
${ }^{1}$ Central Statistics Office (2018). Population and Migration Estimates. Dublin: Central Statistics Office. http://www.cso.ie/en/releaseandpublications/er/pme/populationandmigrationestimatesapril2018. Accessed 27 April 2019.

${ }^{2}$ Commission on Emigration and other Population Problems (1955). Report: Commission on Emigration and other Population Problems 1948-1954. Dublin: Stationary Office.
} 
arrangements with an Irish embassy in a neighbouring country. In 2018, it was announced that Ireland intended to open seven new missions, which will include four new embassies (Ukraine, Morocco, Philippines, Liberia) and three new consulates (Frankfurt, Los Angeles, Cardiff).

In 2014, Ireland appointed a Minister of State for the Diaspora for the first time. The role is located in the Department of Foreign Affairs and Trade (DFA). The main responsibility of the Minister is to communicate the views of the Irish abroad to the Government. The Minister chairs the Interdepartmental Committee on the Irish Abroad. The membership of this Committee comprises 17 Government departments plus five external stakeholders: Bord Bia; Enterprise Ireland; IDA Ireland; Science Foundation Ireland; Tourism Ireland. The Committee acts as a forum in which issues affecting Irish people abroad can be raised and Departments with responsibility for the relevant area can report back to the Committee on their work in resolving these. The Committee meets three times a year.

The Irish Abroad Unit, based in the DFA, manages and coordinates the Emigrants Support Programme (ESP) in partnership with Ireland's embassies and consulates abroad. The ESP funds projects that celebrate, maintain and strengthen links between Ireland and the Irish abroad and that address the diverse and evolving needs of Irish emigrants, especially the elderly, disadvantaged and vulnerable.

The Irish Government has established a number of fora in the past decade in order to consult the Irish diaspora: the Global Irish Economic Forum, the Global Irish Network and the Global Irish Civic Forum. All of these fora are organised and managed by the DFA. In 2009, the first Global Irish Economic Forum (GIEF) was held in Dublin and was attended by the Taoiseach (Prime Minister). Members of the Forum were invited by the DFA. There have been meetings of the Economic Forum every 2 years since then. This first meeting was held in the context of the 2008 financial crash and the onset of Ireland's terms of recovery set by the European Union. The Forum aimed to explore how the Irish at home and abroad could work together to contribute to Ireland's economic recovery; and to examine ways in which Ireland and its global community could develop a more strategic relationship with each other, particularly in the economic sector. The Irish Government viewed the first GIEF as a great success. ${ }^{3}$

The Global Irish Network (GIN) was established in 2010 as a direct result of recommendations at the first GIEF. The Network now comprises over 350 Irish and Irish connected business people based in 40 countries and has three objectives: to provide a platform to assist the Government and state agencies to promote Ireland's economic, cultural and tourism messages in key markets; to provide a forum through which successful Irish business and cultural figures abroad can interact with each other, exchange views and be kept informed of key developments in Government policy; and to provide a forum through which members can put forward proposals and implement practical initiatives. It is members of this Network who are invited to meetings of the GIEF.

The members of the GIN are selected primarily on the recommendation of Irish embassies and consulates, and its members and Advisory Group are appointed by

\footnotetext{
${ }^{3}$ See: https://global.irish/2009Forum.aspx. Accessed 27 April 2019.
} 
the Minister for Foreign Affairs and Trade. The Advisory Group was formed to review progress on GIEF outcomes, coordinate the work programme of the Network and work with ambassadors in keeping the wider Network informed of developments. Nineteen members of the Network accepted the Tánaiste's invitation to join the Advisory Group and its first meeting was in 2012.

In 2015, the first Global Irish Civic Forum (GICF) was also held in Dublin 'to discuss the challenges facing the Irish Abroad' and bring together representatives of over 140 organisations working with the Irish diaspora globally. The Minister for the Diaspora and the Minister for Foreign Affairs and Trade also attended the event, together with 175 delegates from 17 countries. Many of the organisations attending the Forum receive funding through the ESP (though specifically prohibited from utilising that grant money to fund attendance at the GICF). The programme was devised by the DFA not without controversy, e.g. omitting a session on voting rights for citizens abroad. A further GICF was held in 2017 when this omission was rectified.

There has been no direct representation for the Irish abroad in the two houses of the Irish Parliament (the Dail and the Seanad) until recently. In 2016, Billy Lawless, an Irish-born resident of Chicago, was nominated by the Taoiseach as a member of the Seanad (the Senate). This was the first time an emigrant had become a member of this chamber. Also in 2016, Senator Mark Daly was appointed as Senate Spokesperson on Foreign Affairs and Irish Overseas and the Diaspora. Both have been active taking up emigrant issues, in particular on voting rights for citizens abroad.

\subsubsection{Key Engagement Policies}

In 1999, as part of the settlement of the Good Friday Agreement and after a referendum in Ireland, Article 2 of the Irish Constitution was changed. This included a statement that the Irish nation cherishes its special affinity with people of Irish ancestry living abroad who share its cultural identity and heritage. This change had the effect of directing focus on the diaspora. In 2001, the Irish Government set up a Task Force on Policy Regarding Emigrants that was to report to the Minister of Foreign Affairs (the instigation for this came largely from the Catholic Church and the trade union movement). The recommendations of the Task Force Report ${ }^{4}$ covered pre-departure services, support for the Irish abroad and for returning emigrants. The significance of the Task Force Report is that it named emigrants and their descendants as 'the Irish Abroad' and identified them as a constituency whose welfare, cultural and other integration needs, should be considered, and in some cases responded to by the Irish Government (Gray 2006). The recommendations of the

\footnotetext{
${ }^{4}$ Task Force on Policy Regarding Emigrants (2002). Ireland and the Irish Abroad. Dublin: Department of Foreign Affairs.
} 
Task Force Report led to the establishment of the Irish Abroad Unit in the Department of Foreign Affairs in 2004 and to a significant increase in funds available to assist vulnerable Irish people abroad (from 2004 onwards, these funds were available globally, not just in Britain) through the ESP.

With this increased focus on the diaspora, other Irish institutions (universities, Tourism Ireland) and the Government developed various initiatives, one being The Gathering in 2013. The Gathering aimed to mobilize the Irish diaspora to return to Ireland during 2013. It was a Government supported initiative from Fáilte Ireland (National Tourism Development Authority) and Tourism Ireland. It relied on grassroots events organized by individuals, communities and NGOs for which funding was available. The Irish ambassador to Berlin (at the time, Daniel Mulhall), speaking about soft power and national branding, described The Gathering as an example of 'using our international diaspora to benefit Ireland at a time of economic difficulty'. This was a result of the Government coming to realise as it sought to 'develop our national brand', that 'our Irish communities abroad are a very significant source of influence and impact'.5

Unsurprisingly, a key aspect of diaspora policy for the Irish Government is supporting Irish business abroad. There are hundreds of Irish Business Networks across the globe, including the International Business Network based in London, Dublin, Belfast and New York. The Irish Government supports some of these networks through the ESP and by sending Ministers or embassy staff to promote events, holding receptions, providing secretariat assistance, inviting key guests and providing meetings spaces (Boyle and Kavanagh 2018, 71). Another key aspect of Irish diaspora engagement is promoting Irish culture. Through the ESP, the Government supports Irish language initiatives and Irish Studies courses. Culture Ireland, an Irish State Agency funded by the Department of Arts, Heritage and the Gaeltacht, operates funding programmes to support and promote Irish arts internationally.

In 2015, the Irish Government published for the first time a definitive version of its diaspora policy: Global Irish. Ireland's Diaspora Policy. ${ }^{6}$ The notion of 'Global Irish' invokes a powerful national imaginary visualised not as a small island of 6 million people located at the edge of Europe, but as a globally networked community of 6 million people in Ireland with over 1 million Irish born, 3 million citizens, and as many as 70 million people of Irish descent living overseas. Global Irish sets out the Government's intention to consider that 'the Irish at home and the Irish abroad are one community' (p. 19).

The objectives of Ireland's diaspora policy include fostering diaspora engagement in a way that those, who having left Ireland, are in need of support receive it

\footnotetext{
${ }^{5}$ Mulhall, D. (2012). Lecture to The Berlin International Economics Congress 7 March 2012. Berlin: Institute for Cultural Democracy. http://www.culturaldiplomacy.de/mediacenter/index. php?he-amb-dan-mulhall-ambassador-of-ireland-to-germany-berlin-march-7th-10th-2012. Accessed 27 April 2019.

${ }^{6}$ Department of Foreign Affairs (2015). Global Irish. Ireland's Diaspora Policy. Dublin: Department of Foreign Affairs.
} 
and that those who are Irish or of Irish descent who wish to maintain a connection with Ireland or to each other are able to do so.

There has been criticism of Ireland's diaspora engagement policies (Gray 2006, 2012; Boyle et al. 2013; Boyle and Kavanagh 2018; Devlin Trew 2018). These include commenting on its overwhelming economic motivation as it seeks either to make money or cultural capital out of the Irish diaspora. Others criticize that the policy has done little to rectify the fact that Irish citizens become disenfranchised after being out of the country for over 18 months $^{7}$ (see Honohan 2011). The publication of Global Irish in 2015 was in part an answer to such criticisms, with its emphasis on the wide-ranging nature of Ireland's engagement with and support for its diaspora.

The Global Irish policy aims to facilitate a wide range of activities at local, national and international level designed to develop two-way diaspora engagement; and recognises that the policy will evolve to meet changing needs and times. All diaspora engagement by Ministries/agencies in Ireland is managed within the context of the objectives, policies and guidelines delineated in Global Irish. In the next section of the chapter, those activities concerned with social protection for the Irish diaspora are discussed.

\subsection{Diaspora Policies and Social Protection in Ireland}

Ireland has 80 embassies, consulates and honorary consulates around the world. Through these consulates, Ireland offers services to their citizens abroad, some of which encompass basic social protection. The gist of Irish substantive law on the issue is contained in the Diplomatic Relations and Immunities Act 1967 (which in its preamble makes it clear that this Act is implementing, inter alia, the two International Conventions concerning Diplomatic and Consular Relations). The Vienna Convention on Consular Relations (VCCR) was made part of Irish law (section 6 of the 1967 Act). Thus, relevant articles in the 1967 Convention, such as Article 7 dealing with exercise of consular functions in a third state, are part of Irish law. This law may be viewed as giving the basis for Irish nationals to claim diplomatic or consular assistance abroad, though officially Ireland does not provide statutory protection in this regard as a right, but rather as a matter of a policy under which consular protection is in practice never refused.

On the DFA website, there are details of Ireland's Consular Assistance Charter. It outlines clearly that consular interventions are limited to: offering advice and support in cases of family and other emergencies; offering linguistic and cultural support on who to contact and how things are done locally; issuing emergency travel documents; contacting a citizen's friends or family on their behalf; providing advice on health services and security issues in the host country. The Charter clarifies that

\footnotetext{
${ }^{7}$ See also: www.vica.ie. Accessed 27 April 2019.
} 
Irish consulates cannot provide medical or legal advice, that they do not have a budget for medical, legal or other expenses, cannot influence the visa decisions of other countries and do not deal with commercial or insurance disputes.

Irish consulates do not fund the repatriation of a deceased person's body from abroad. They will help the family of the deceased liaise with the relevant authorities including police, coroners in the country where the death occurred and with the relevant authorities in Ireland especially in relation to funeral arrangements. In very exceptional circumstances where the health or security of an Irish citizen abroad is at risk, the Department of Foreign Affairs and Trade may agree to repatriate the person to Ireland. Repatriation in this instance is subject to strict conditions which are set out in each individual case (no guidelines available). The conditions include a written undertaking to repay all the expenses incurred, as well as a statutory fee for this service.

Citizens abroad seeking help or advice can also consult the Citizens Information Board, ${ }^{8}$ i.e. the statutory body which supports the provision of information, advice and advocacy on a broad range of public and social services. The Board comes under the remit of the Department of Employment Affairs and Social Protection. It has a section on Leaving Ireland which includes, for example, information about citizens abroad entitlements to social security, both social security arrangements Ireland has with other countries and details of Irish social welfare payments that can be paid abroad. The Crosscare Migrant project ${ }^{9}$ is a Dublin-based NGO providing information and advocacy support to Irish emigrants and people who have moved to Ireland (including returning migrants). It is partly funded by the Emigrant Support Programme (ESP). Crosscare is the social support agency of the Dublin Catholic Archdiocese. The migrant project provides information for citizens abroad, those thinking of leaving and those thinking of returning.

There are two main principles which govern the offering by the Irish Government of social protection to citizens abroad. First, that in Ireland, a Habitual Residency Condition governs the right to a variety of social assistance. Second, that Irish Government organizations abroad do not supply material assistance in the social protection areas examined. However, the Irish Government considers that it lives up to its commitments to the welfare of its citizens abroad by funding the ESP. Under this programme, hundreds of organizations are funded worldwide to support their activities in providing advice and material assistance to Irish people living outside the state.

The Habitual Residency Condition underpins a particular perception of an individual's right to social assistance in Ireland. The term 'habitually resident' (according to Citizens Information) is not defined in Irish law, but in practice means that one has a proven close link to Ireland and implies a degree of permanence. To be considered 'habitually resident' requires to have a legal right to reside in Ireland.

${ }^{8}$ Citizens Information Board. http://www.citizensinformation.ie/en/moving_country/moving abroad/leaving_ireland/leaving_ireland_and_your_social_security_entitlements.html. Accessed 27 April 2019.

${ }^{9}$ Crosscare Migrant Project. http://www.migrantproject.ie/leaving-ireland. Accessed 27 April 2019. 
Five factors are examined to establish access to social assistance: length and continuity of residence in Ireland; length and purpose of absence from Ireland; nature and pattern of employment; an individual's main centre of interest; and future intentions to live in Ireland as it appears from the evidence.

For all social welfare payments in Ireland, an individual must satisfy the rules for each scheme to qualify. They must be habitually residents to qualify for the following payments: Back to Work Family Dividend; Blind Pension; Carer's Allowance; Child Benefit (partial exceptions, see below); Disability Allowance; Domiciliary Care Allowance; Guardian's Payment (non-contributory); Jobseeker's Allowance; One-Parent Family Payment; State Pension (non-contributory); Supplementary Welfare Allowance; Widow's, Widower's or Surviving Civil Partner's (noncontributory) Pension. Nationality is not a requirement to receive these benefits, being 'habitually resident' is a requirement.

Under EU law, in certain circumstances, the habitual residence condition does not have to be satisfied. This applies to Family Benefits (Back to Work Family Dividend, Child Benefit, Domiciliary Care Allowance, Guardian's Payment, noncontributory, Working Family Payment, and One-Parent Family Payment) and to Supplementary Welfare Allowance. This exception primarily applies to European Economic Area (EEA) and EU citizens regarded as migrant workers due to their engagement in genuine and effective employment in Ireland. Returning Irish migrants do not benefit from this exception. In order to satisfy the Habitual Residence Condition, they have to prove that they have made Ireland their home again. However, according to Department of Employment Affairs and Social Protection Operational Guidelines, a person who had previously been habitually resident in the state and who moved to live and work in another country and then resumes his/her long-term residence in the state, may be regarded as being habitually resident immediately on his/her return to Ireland (Crosscare Migrant Project).

The following social welfare payments can be paid abroad: Invalidity Pension; State Pension (contributory); Disablement Benefit; Guardian's Payment (contributory); Widow's, Widower's or Surviving Civil Partner's (contributory) Pension; Death Benefits under the Occupational Injury Benefit Scheme; and Bereavement Grant. If going abroad for a long period of time or permanently, an individual must notify the Department of Employment Affairs and Social Protection and will be asked to produce evidence of continuing to fulfil the qualifying conditions for the payment.

In the main, however, the Irish Government's social protection policy as regards the Irish diaspora involves offering support to Irish welfare, community and advocacy organizations which originate in the diaspora itself. This is central to the approach of the Emigration Support Programme (ESP), managed and administered by the Irish Abroad Unit in partnership with Ireland's embassies and consulates. The premise of the ESP is that it cannot replace social welfare supports in Irish citizens' countries of residence. Instead, working with civil society partners, it can help people access those services to which they are entitled. The ESP was established in 2004 and following the recommendations of the Task Force on Policy Regarding Emigrants, it was designed to extend social protection and welfare relief to vulnerable Irish citizens living abroad. The Government views the ESP as a tangible 
expression of its commitment to strengthen the international Irish community and its bond with Ireland. In the period 2004-2018, grants totalling over $€ 170 \mathrm{~m}$ have been dispensed through the ESP to over 530 organisations in 36 countries.

The programme funds projects that range from celebrating, maintaining and strengthening links between Ireland and the Global Irish to addressing the diverse and evolving needs of Irish emigrants (especially the elderly, disadvantaged and vulnerable) or facilitating access to statutory and voluntary services in the country of settlement. The ESP also supports strategic initiatives within its overall framework such as research about the emerging needs of Irish communities abroad and the development of new ways to communicate and connect with the increasingly diverse global Irish. ${ }^{10}$

Welfare is central to the ESP and this primarily explains why the highest proportion of the funds are allocated to organizations in Britain, where the largest number of Irish-born people reside outside Ireland (three-four times as many as reside in the United States, for example). In 2017, €5,318,687 in funds were allocated in Britain out of a budget of $€ 11,676,521$; $€ 3,945,181$ was awarded in grants to organizations in the United States. Funds were dispensed to organizations in 23 countries, the smallest allocation was $€ 25,000$ to Zimbabwe. In Britain, which has been the prime destination of Irish emigrants since the 1930s, many emigrants are ageing. Due to their previous occupations, they often live with a range of vulnerabilities from accommodation issues to social isolation to mental health issues. The provision of advice and support for the elderly is at the core of many grants which the ESP awards, for example, funding the organisation, administration and quality assurance of a network of volunteers to provide regular home visits to those unable to leave their homes.

The ESP operates with an online application process. It currently publicises that it is interested in funding applications that fulfil the objectives that include welfare, connectedness, intergenerational links and collaborative projects. Projects that reflect diversity within the Irish diaspora and Irish communities are also specifically encouraged. The criteria for awards is clearly set out on the Irish Abroad Unit's section of the DFA website as is the downloadable form. There is one annual deadline for receipt of applications, usually early in the year, and the application process opens about a month before this. The funding year runs from July 1st to 30th June.

\subsubsection{Unemployment}

As provided by EU legislation, an unemployed individual who receives unemployment benefits can leave the country to search for work in another EU Member State and continue to temporarily receive unemployment benefit. Beyond this, there are various information sources to assist Irish citizens seeking employment abroad.

\footnotetext{
${ }^{10}$ Department of Foreign Affairs (2015). Global Irish. Ireland's Diaspora Policy. Dublin: Department of Foreign Affairs.
} 
The emphasis is on helping citizens find work, rather than responding to the hardship of the state of unemployment. The Citizens Information website has a section on 'Moving abroad from Ireland' which gives directions for finding out information about the country an individual is moving to. Crosscare Migrant Project, which is partly funded by the ESP, gives advice about leaving Ireland on its website.

The ESP does not have employment or unemployment in the destination country as an explicit part of its mission. It partially funds some advice centres in the diaspora for Irish emigrants that would include advice about job opportunities both in the host country and in Ireland. However, as many of the emigrants needing support are elderly advice on employment is most likely to be included by some of the larger, more general advice and welfare organisations. An applicant organisation could make the case that this is a necessary part of providing support for the welfare of Irish emigrants abroad. Once a grant is received on this basis, it is monitored and 'in effect' forms a contract with the DFA. There is no difference between countries on this.

The ESP funds (usually partially) some of these general advice centres for Irish emigrants that include advice about job opportunities both in host country and in Ireland. For example, in the UK, the London Irish Centre provides advice on moving to London that includes advice on finding employment. In the USA, the Aisling Center in Yonkers, New York provides counseling in this area. As does the Irish Canadian Immigration Centre in Toronto, Canada.

\subsubsection{Health Care}

On the Department of Foreign Affairs (DFA) website there is clear information that if sick or injured abroad, an Irish citizen can contact the consulate for advice on finding English-speaking medical help and assistance to contact relatives. If ill or had an accident, Irish consulates will inform family and friends, advise on local medical services, provide lists of English-speaking doctors, and liaise with local medical services. This information is also available on the Citizens Information website. In very exceptional circumstances where the health of an Irish citizen abroad is at risk and there is no way of dealing with the situation satisfactorily locally, the DFA may agree to repatriate the person to Ireland. This is done at the discretion of the Department and involves a written undertaking from the individual to repay all the expenses incurred, as well as a statutory fee for the service.

Under ESP funding, many of the organisations who receive grants include support for people with health issues, if only because so many are focused on the elderly Irish. The needs of the elderly are a specific concern of the ESP and this includes their physical and mental health. For example, in the UK, Leeds Irish Health \& Homes deliver advice and help about health matters. In the USA, giving advice on health insurance is often what is needed, for example, the Emerald Isle Immigration 
Centre in New York City gives such advice as part of their provision of social services.

Ireland has a Reciprocal Healthcare Agreement with Australia since 1997. The Agreement enables visitors from Ireland to Australia (including people with valid Working Holiday or Temporary Skilled Worker visas, these individuals form a majority of Irish migrants to Australia) to receive medically necessary treatment as inpatients or outpatients in Australian public hospitals. The equivalent care is provided in Ireland for visitors from Australia. Also the Irish Support Agency, based in Sydney and funded by the ESP, gives advice on mental health issues.

More generally, if an individual has qualified for an Invalidity Pension while living in Ireland, this pension is an example of a pension that can be paid while the claimant is living abroad (Disablement Benefit falls in the same category with some caveats). Invalidity Pension is also an example of a pension for which it is possible to combine an individual's insurance record in the destination country (if that country is in the EU or one with which Ireland has a bilateral social security agreement) with an individual's Irish PRSI (social insurance) contributions.

\subsubsection{Pensions}

The Citizens Information website gives information about claiming certain pensions while abroad. The Invalidity Pension, State Pension (contributory), Widow's, Widower's or Surviving Civil Partner's (contributory) Pension are all paid to qualifying individuals outside the state.

The Emigrant Support Programme (ESP) has no specific objective as regards pensions; but it is concerned about the 'diverse and evolving needs of Irish emigrants, especially the elderly' which can include pensions. Many of the organisations funded by the ESP are either specifically aimed at the elderly or have their welfare as one of their major goals, the ESP has consistently made this a priority. This includes in many instances giving advice about claiming a pension in Ireland and/or the country of residence.

In countries with which Ireland has reciprocal agreements, information is provided about an individual's prior pension contributions. For instance, the main purpose of the bilateral Social Security Agreements that Ireland signed with Australia and the United States is to protect the pension rights of people who have worked and paid reckonable social security contributions in the signing countries. Both Agreements do this by allowing social security contributions paid in one signing country to be counted towards qualifying for certain payments in the other country. There is a similar arrangement in place between Ireland and Canada, the Irish/ Canadian Social Security Agreement. 


\subsubsection{Family-Related Benefits}

A key aspect of Irish citizenship law is that if a child is born outside Ireland to a national born in Ireland, the child is automatically an Irish citizen and there is no need for an Irish birth certificate. The birth certificate in the country of birth suffices (for example, when applying for an Irish passport) and therefore Irish consulates are not involved in the process.

Family-related state benefits are payable for a limited time while a citizen is abroad, except for Child Benefit. Maternity Benefit is paid for a maximum of 6 weeks while a citizen is outside Ireland. Paternity Benefit is paid for a maximum of 2 weeks while abroad. Adoptive Benefit is available for up to 6 weeks while abroad. Child Benefit can be paid to volunteer development workers and members of the Irish Defence Forces or Irish Civil Service serving abroad. It can also be paid if one is working abroad for an Irish employer and paying Irish social insurance contributions (Citizens Information 2019).

The ESP has no specific mission of responding to the needs of families, it depends what NGOs in the diaspora present to them in their applications for ESP funding. It is possible to make a case for such funding under general criteria of the ESP. It is quite clear to applicants that these and other benefits are the type which an organisation can apply for a grant with which to provide advice and assistance. NGOs have leeway about what to make a case about for funding as long as it comes under the ESP's broad funding criteria which are clearly outlined on its website.

Many Irish welfare organisations which the ESP part funds offer advice on accessing benefits in both Ireland and the country of residence. Examples are the London Irish Centre, the Aisling Irish Community Centre in Yonkers, USA, and the Irish Support Agency in Sydney.

\subsubsection{Economic Hardship}

The DFA website makes it quite clear that Irish consulates do not provide cash benefits under any circumstances. Furthermore, Ireland's Basic Supplementary Welfare Allowance, meant to be available for cases of economic hardship, is not available to citizens living abroad.

The Irish authorities consider they assist people in economic hardship while living abroad through their funding of Irish welfare organisations in many countries in the diaspora under the ESP. Any diaspora organisation can apply for funding as long as they satisfy the relevant criteria, which can vary from year to year. Consequently, consulates may often refer individuals who approach them in economic hardship to an organisation in the destination country that the Irish Government funds which they know deals with the relevant matter.

In the UK, the ESP funds the Benefits Advice Shop. In the USA, Chicago Irish Immigrant Support, funded by the ESP, offers relevant advice in this area. In 
Australia, the Irish Australian Support and Resource Bureau, based in Melbourne, gives assistance to those in distress. The Irish Canadian Immigration Centre in Toronto also offers relevant advice.

\subsection{Conclusions}

Ireland is a small country with a large diaspora, this perception of Ireland's relative resources in part lies behind its smaller than average network of consulates and their clearly delineated and limited responsibilities. Since the turn of the century, and especially since the financial crash in 2008, Ireland has focused more on the diaspora than before, both for the economic and cultural benefits that may accrue to Ireland and to fulfil its commitments to the welfare of Irish emigrants and their children abroad and to strengthening ties between Ireland and its diaspora.

In 2015, the Department of Foreign Affairs and Trade (DFA) published Global Irish, this was a landmark document clearly setting out Ireland's diaspora policy and Ireland's interests and responsibilities that flowed from this. This policy is being reviewed and revised during 2019 as part of Ireland's new statement of foreign policy, Global Ireland 2025. This is a plan to double Ireland's international footprint by 2025 , and a new diaspora policy will be developed in this context.

The main criticisms of Ireland's diaspora policy are about its overwhelming economic motivation as it seeks either to make money or cultural capital out of the Irish diaspora. There is in Ireland a paradox, probably generated by its extensive history of emigration, between the assumed strength of association with Ireland entailed in being a resident compared with being a citizen. As has been outlined, this impacts extensively on the social protection benefits available to Irish people abroad, with a large list of benefits requiring a Habitual Residency Condition to be satisfied.

After 2008, the focus on the diaspora was on it helping to provide policy solutions in Ireland's time of need. Subsequently, a much wider interpretation of Ireland's diaspora policy and of the relationship between Ireland and its diaspora was outlined in the publication Global Irish (DFA 2015). However, this period has also highlighted the contradiction between residency and citizenship and this has come to a head in the campaign for voting rights for Irish citizens abroad. The Irish Government has made a first step towards rectifying this democratic deficit by announcing that it is committed to holding a referendum about extending the right to vote in presidential elections to citizens abroad.

Acknowledgements This chapter is part of the project "Migrant and Transnational Social Protection in (Post) Crisis Europe (MiTsoPro)" that has received funding from the European Research Council (ERC) under the European Union's Horizon 2020 research and innovation programme (Grant agreement No. 680014). In addition to this chapter, readers can find a series of indicators comparing national social protection and diaspora policies across 40 countries on the following website: http://labos.ulg.ac.be/socialprotection/. 


\section{References}

Boyle, M., \& Kavanagh, J. (2018). The Irish government's diaspora strategy: Towards a care agenda. In J. Devlin Trew \& M. Pierse (Eds.), Rethinking the Irish diaspora. After the gathering (pp. 59-79). Cham: Palgrave Macmillan.

Boyle, M., Kitchin, R., \& Ancien, D. (2013). Ireland's diaspora strategy: Diaspora for development? Maynooth University eprints. http://mural.maynoothuniversity.ie/7312/1/RK-Irelandsdiaspora.pdf

Citizens Information (2019) Accessed on 19 March 2019 at: http://www.citizensinformation. ie/en/social_welfare/irish_social_welfare_system/claiming_a_social_welfare_payment/ going_abroad_and_social_welfare_payments

Devlin Trew, J. (2018). Diaspora engagement in Ireland, North and South, in the Shadow of Brexit. In J. D. Trew \& M. Pierse (Eds.), Rethinking the Irish diaspora. After the gathering (pp. 15-57). Cham: Palgrave Macmillan.

DFA (2015) Global Irish. Ireland's diaspora policy. Dublin: Department of Foreign Affairs and Trade.

Glyn, I., Kelly, T., \& Mac Éinrí, P. (2013). Irish emigration in an age of austerity. Cork: University College Cork.

Gray, B. (2006). Migrant integration policy: A nationalist fantasy of management and control? Translocations, 1(1), 118-138.

Gray, B. (2012). Irish state diaspora engagement - "The Network State" and "Netizens". EireIreland, 47, 244-270.

Honohan, I. (2011). Should Irish emigrants have votes? External voting in Ireland. Irish Political Studies, 26(4), 545-561.

Walter, B., Gray, B., Almeida Dowling, L., \& Morgan, S. (2002). Irish emigrants and Irish communities abroad. Dublin: Department of Foreign Affairs.

Open Access This chapter is licensed under the terms of the Creative Commons Attribution 4.0 International License (http://creativecommons.org/licenses/by/4.0/), which permits use, sharing, adaptation, distribution and reproduction in any medium or format, as long as you give appropriate credit to the original author(s) and the source, provide a link to the Creative Commons license and indicate if changes were made.

The images or other third party material in this chapter are included in the chapter's Creative Commons license, unless indicated otherwise in a credit line to the material. If material is not included in the chapter's Creative Commons license and your intended use is not permitted by statutory regulation or exceeds the permitted use, you will need to obtain permission directly from the copyright holder.

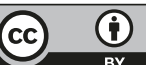

